\title{
High Risk Strawberry Viruses by Region in the United States and Canada: Implications for Certification, Nurseries, and Fruit Production
}

Robert R. Martin, Horticultural Crops Research Laboratory, United States Department of Agriculture-Agricultural Research Service, Corvallis, OR 97330; and Ioannis E. Tzanetakis, Department of Plant Pathology and Cell and Molecular Biology Program, Division of Agriculture, University of Arkansas, Fayetteville 72701

\begin{abstract}
Martin, R. R., and Tzanetakis, I. E. 2013. High risk strawberry viruses by region in the United States and Canada: Implications for certification, nurseries, and fruit production. Plant Dis. 97:1358-1362.

There is limited information about the distribution of strawberry viruses in North America and around the world. Since the turn of the century, there has been a concerted effort to develop sensitive tests for many of the previously uncharacterized, graft-transmissible agents infecting strawberry. These tests were employed to determine the presence of strawberry viruses in major strawberry production and nursery areas of North America. The viruses evaluated in this study were Apple mosaic, Beet pseudo-yellows, Fragaria chiloensis latent, Strawberry chlorotic fleck, Strawberry crinkle, Strawberry latent ring spot, Strawberry mild yellow edge, Strawberry mottle, Strawberry necrotic shock, Strawberry pallidosis, Strawberry vein banding, and Tobacco streak.

whereas the whitefly-borne viruses were prevalent in California, the Midwest, and the Southeast. In the Northeast, the aphid-transmitted Strawberry mottle and Strawberry mild yellow edge viruses along with the whitefly-transmitted viruses were most common. The incidence of pollen-borne viruses was low in most areas, with Strawberry necrotic shock being the most prevalent virus of this group. These results indicate that there are hotspots for individual virus groups that normally coincide with the presence of the vectors. The information presented highlights the high-risk viruses for nursery production, where efforts are made to control all viruses, and fruit production, where efforts are made to control virus diseases.
\end{abstract} The aphid-borne viruses were predominant in the Pacific Northwest
Approximately 250,000 ha of strawberry (Fragaria $\times$ ananassa, Duch.) are grown worldwide, with production exceeding 4 million tons in 2010 (2). The United States leads in world production, with about 1.3 million tons and crop value of over \$2 billion for 2009 (3). Canada produces much less fruit (20,000 tons) but has an important role in North American production: a significant number of plants grown for fruit production in the United States are grown in nurseries in Canada to receive their chilling requirements for flower bud initiation. This practice can have a major impact on pathogen trafficking and has the potential to be a key factor in the onset of strawberry decline (SD), the reason for undertaking the study presented here.

Symptoms of SD include leaf discoloration, chlorosis, reddening, stunting of root system and leaves, and progressively weakened plants that have little or no marketable fruit and, in several cases, die before harvest (Fig. 1). Symptoms were observed on a wide range of cultivars, including 'Totem' and 'Puget Reliance', that had not developed symptoms of virus infection previously; 'Camarosa' and 'Ventana' in California; and 'Radiance' and 'Mira' in Nova Scotia. The disease affected strawberry plants from British Columbia, Canada to southern California between 2000 and 2003 and along the east coast in 2012 (Nova Scotia, Canada to Florida). It peaked in California in 2003 but continues to be a problem in northern Washington State and the Fraser River valley in British Columbia, Canada (R. R. Martin, personal observation). In California, where strawberry is grown as an annual crop, symptoms of

\section{Corresponding author: R. R. Martin, E-mail: bob.martin@ars.usda.gov}

* The $\boldsymbol{e}$-Xtra logo stands for "electronic extra" and indicates that Figure 1 appears in color in the online edition.

Accepted for publication 5 April 2013.

http://dx.doi.org/10.1094/PDIS-09-12-0842-RE

This article is in the public domain and not copyrightable. It may be freely reprinted with customary crediting of the source. The American Phytopathological Society, 2013. decline are generally rare. However, in 2002 and 2003, symptoms were common in production fields, with an estimated loss of more than $\$ 50$ million for the 2002 and 2003 seasons (M. Bolda, personal communication).

California fields were heavily infested with whiteflies, primarily the greenhouse whitefly, Trialeurodes vaporariorum. Symptomatic plants were tested for two strawberry viruses transmitted by the greenhouse whitefly: Beet pseudo-yellows virus (BPYV) and Strawberry pallidosis associated virus (SPaV) $(26,27)$. The incidence of BPYV and SPaV exceeded 40 and $75 \%$, respectively, in southern California fields, with the incidence of $\mathrm{SPaV}$ exceeding $90 \%$ in Orange County fields (17). Grafting of both viruses onto 'Hood' and 'Noreaster' strawberry, cultivars that readily exhibit symptoms of virus infection, did not cause any decline-like symptoms (17), leading to the hypothesis that the disease is caused by the synergistic effects of multiple viruses.

The 1998 American Phytopathological Society strawberry compendium listed eight viruses with available laboratory detection tests, and there were several virus-like agents listed with grafting as the sole detection method available. The incidence of SD led us investigate several of the graft-transmissible diseases of the crop and we now know that there are about 30 virus species infecting strawberry $(8,23,24)$, with diagnostic assays developed for all but two of the reported viruses, Strawberry latent C and Strawberry pseudo mild yellow edge viruses, for which isolates were not available. Given the severity of the SD and plant movement across state and country lines, we used the newly developed assays and tested for 12 viruses to determine their incidence in areas with high vector and disease incidence as well as areas without recorded strawberry virus problems. This knowledge will be used to identify high-risk viruses of strawberry by region, help to improve certification programs, reduce the risk of movement of virusinfected planting stock from heavily infected areas, and implement measures to minimize virus disease impact on fruit production.

\section{Materials and Methods}

Plant material. Samples were collected from the field randomly (with the exception of declining plants in California) and either 
brought back or shipped to the United States Department of Agriculture-Agricultural Research Service (USDA-ARS) Horticultural Crops Research Laboratory in Corvallis, OR or the Department of Plant Pathology at the University of Arkansas between 2002 and 2012. Areas of collection were California, the Pacific Northwest (Oregon and Washington in the United States and British Columbia, Canada); the Midwest (Michigan, Minnesota, Missouri, Ohio, and Wisconsin in the United States and Ontario, Canada), the Southeast (Arkansas, Florida, North Carolina, South Carolina, and Virginia), and the Northeast (Maryland, Massachusetts, and New York in the United States and Nova Scotia, Canada).

A decline (stunting and reddening) of strawberry plants was observed in the Great Village area of Nova Scotia in the autumn of 2012 (J. Lewis, personal communication, and R. R. Martin, personal observation). Samples were collected in October 2012 and shipped to the USDA-ARS laboratory in Corvallis, OR. In addition, nursery plants that had originated in the Great Village area and other locations in eastern Canada that had been shipped and planted in the southeastern United States for fruit production were collected, sent to the USDA-ARS laboratory in Corvallis, OR and tested in late 2012.

Nucleic acid extractions. Total nucleic acids (TNAs) from declining plants from California were extracted using the Spiegel and Martin (13) protocol. For the remaining samples, TNA was extracted using the protocol described by Tzanetakis et al. (19). In all cases, TNA was extracted from about $0.1 \mathrm{~g}$ of leaf tissue surrounding the main vein of young but fully matured leaves to guarantee detection of the phloem-limited criniviruses. Material was eluted in $100 \mu$ of 10:1 Tris-EDTA (10 mM Tris containing $1 \mathrm{mM}$ EDTA), $\mathrm{pH}$ 8.0, and was used immediately for downstream reactions or stored at $-80^{\circ} \mathrm{C}$.

Detection. Reverse-transcription (RT) reactions $(50 \mu \mathrm{l})$ consisted of $50 \mathrm{mM}$ Tris acetate $(\mathrm{pH} 8.4), 75 \mathrm{mM}$ potassium acetate, 8 $\mathrm{mM}$ magnesium acetate, $20 \mathrm{mM}$ dithiothreitol, $0.4 \mathrm{mM}$ dNTPs, 0.3 $\mu \mathrm{g}$ of random primers, and $60 \mathrm{U}$ of Superscript III RT (Invitrogen). The solution was vortexed, centrifuged briefly, incubated at room temperature for $2 \mathrm{~min}$, and then incubated at $50^{\circ} \mathrm{C}$ for $60 \mathrm{~min}$. The reactions were terminated by $15 \mathrm{~min}$ of incubation at $75^{\circ} \mathrm{C}$. After termination, the reactions were diluted fourfold and the diluted cDNA constituted $2.5 \%$ of the total polymerase chain reaction (PCR) reaction volume to prevent inhibition from plant secondary metabolites carried over from the TNA extraction. Before virus detection, all samples were submitted to PCR for amplification of the NADH dehydrogenase ND-2 subunit as described (25), to ensure high RNA quality. Virus-specific PCR reactions (Table 1) were carried out using a PCR program consisting of initial dena- turation for $2 \mathrm{~min}$ at $94^{\circ} \mathrm{C}$; followed by 40 cycles with denaturation for $30 \mathrm{~s}$ at $94^{\circ} \mathrm{C}$, annealing for $30 \mathrm{~s}$ at 52 to $58^{\circ} \mathrm{C}$, depending on the primers (Table 1), and extension for $60 \mathrm{~s}$ at $72^{\circ} \mathrm{C}$; with a final 10 min extension step at $72^{\circ} \mathrm{C}$. Amplification products were resolved by electrophoresis through a $2 \%$ agarose gel containing ethidium bromide or GelRed. Representative amplicons were sequenced to confirm their identity. In the case of Fragaria chiloensis latent virus (FCILV), all amplicons were sequenced to confirm the identity of the virus because it had not been reported in North America previously.

\section{Results and Discussion}

Strawberry is the most important of the berry crops because it is grown in temperate regions around the world and has an economic impact that is measured in the billions of dollars. There are several significant pathogens that cause significant diseases in strawberry, including several Phytophthora cactorum and P. cinnamomi, Colletotrichum acutatum, Macrophomina phaseolina, and Xanthomonas fragariae (10), and viruses have been considered pathogens of minor importance for the crop in areas where it is grown in annual plasticulture systems that most growing areas have adapted. Viruses in strawberry cause significant diseases in areas that use a perennial matted-row production system and where the virus vectors overwinter. Therefore, it was unexpected to observe the viruscaused decline in California, where virtually all production is based on an annual plasticulture system. The great number of novel viruses identified in the last decade and the virus disease outbreaks documented made work toward identification of the major strawberry viruses in North America a necessity. The present is the first extensive study on the presence of major strawberry viruses in North America. The virus spatial distribution was greatly influenced by the presence or absence of vectors, as expected; alas, there were cases where vectors were absent from commercial fields but several samples were infected with viruses, indicative of virus movement through propagation material.

Previous work indicated that several new viruses were present in these plants (17). Given that there was no knowledge of the new viruses, and grafting, the preferred detection method at the time for nurseries, may have not been appropriate for some of them, it can be speculated that some of the viruses may have moved to production fields through the propagation stock. On the other hand, it is only recently that whitefly-transmitted viruses have been discovered in the crop. Previously, there were no control measures implemented for whiteflies in either nursery systems or fruiting fields. In addition, the invasive greenhouse whitefly has recently become naturalized in California (11). The presence of a new vector that was not being controlled is probably the reason that the two crini-
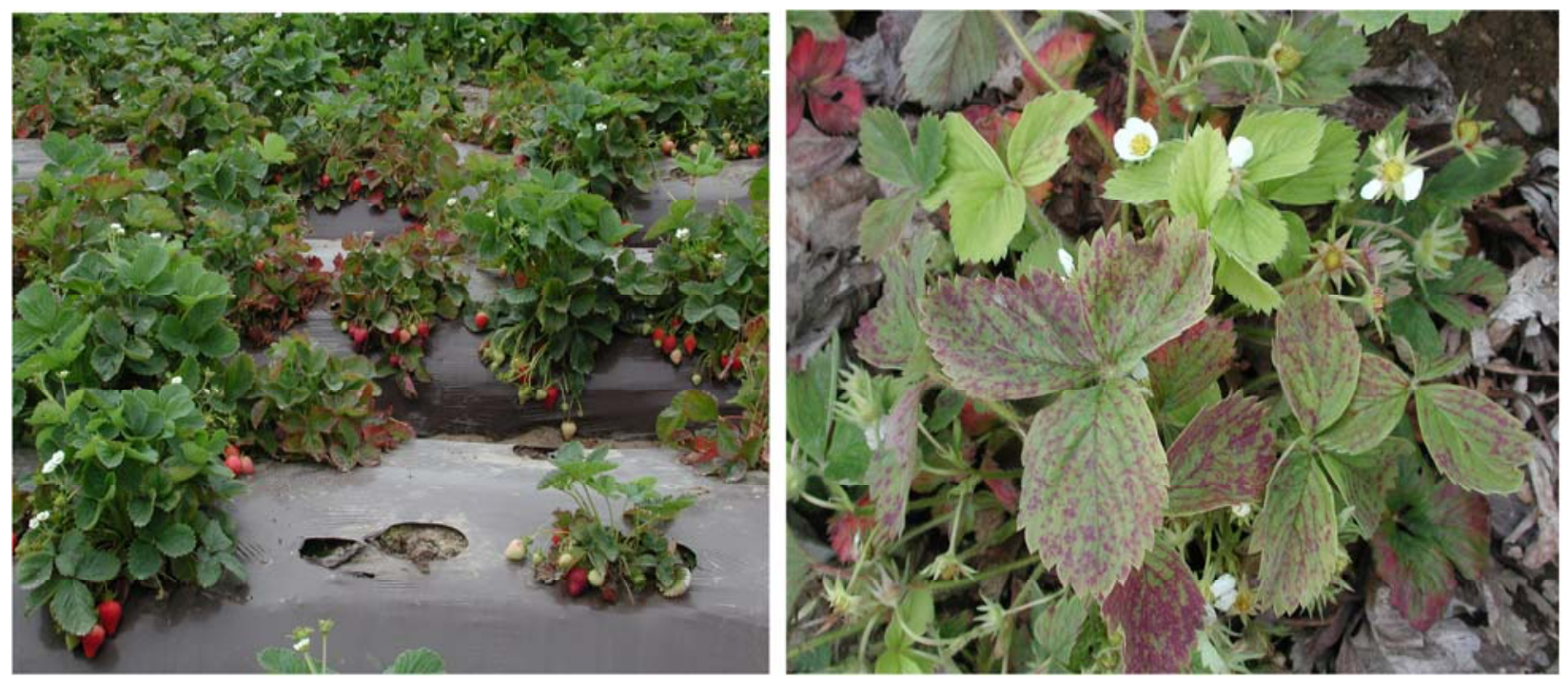

Fig. 1. Symptoms of strawberry decline in California 'Ventana' (left) and British Columbia 'Totem' (right). 
viruses, BPYV and $\mathrm{SPaV}$, were so prevalent in areas where the greenhouse whitefly was present.

The viruses detected in the major strawberry production areas in the United States and Canada are shown in Table 2 and high-risk strawberry viruses by region are shown in Figure 2. Apple mosaic virus and Strawberry chlorotic fleck associated virus [replaced "SCFaV"] were not detected in any of the samples; also, none of the samples tested positive for Tobacco streak virus (TSV) because primers that differentiate between TSV and Strawberry necrotic shock virus were used, and these data are not included in Table 2. FCILV was only detected in samples from the Midwest, and these amplicons were sequenced to validate the PCR product because, previously, this virus had only been reported in germplasm from Chile (14). One can speculate on the source of this virus in the Midwest but considerably more testing would be required to identify the likely source of this virus. However, its presence in North America does highlight the importance of evaluating strawberry germplasm for nonindigenous viruses before release into the environment.

Plants that exhibited decline symptoms always had mixed virus infections. Thus, virus diseases in strawberry are caused by various complexes and disease control does not require controlling all the viruses. In the Pacific Northwest, there were always at least three of the four major aphid-borne viruses present whereas, in California, it was always a combination of at least one aphid-borne virus and at least one whitefly-transmitted virus. Declining plants were co-infected with as many as seven viruses.

In addition, Totem, a cultivar released in 1972 that has been the primary cultivar grown in the Pacific Northwest since about 1980, had not exhibited virus decline symptoms previously but was dramatically impacted by a virus complex since 2000. Also, Puget Reliance, released in 1995 and selected under severe virus pressure (12), developed similar decline symptoms after 2000. In earlier work, 1960s to mid-1980s, Strawberry crinkle virus (SCV) had been detected very rarely in British Columbia (R. Stace-Smith, personnel communication; R. R Martin, unpublished data, 1984 to 1986). The earlier work was based on detection by graft transmission rather than by RT-PCR, which was used in this study. It should be noted that strawberry samples collected from the Fraser River valley in northern Washington and British Columbia in this study and grafted onto Fragaria vesca indicators induced symptoms typical of SCV. SCV is a rhabdovirus that replicates in the aphid vector and has a latent period of at least 6 days under optimal conditions whereas, under less than optimal conditions, the latent period is increased to as much as 50 days (5). It has been speculated that SCV was not observed in northern areas where the strawberry aphid was plentiful due to an extended latent period, such that most aphids died before they were able to transmit the virus. If this is the case, what has happened since 1990 to have SCV become very common in the Fraser River valley? Is there a new strain of the virus? A new biotype of the aphid vector? Have environmental

Table 1. Primer pairs, annealing temperature (Temp), and amplicon size (Size) for each of the viruses tested ${ }^{\text {a }}$

\begin{tabular}{|c|c|c|c|c|}
\hline Virus & Primer pair & Temp $\left({ }^{\circ} \mathbf{C}\right)$ & Size (bp) & Reference $^{\mathrm{b}}$ \\
\hline \multirow[t]{2}{*}{ Apple mosaic virus } & F GTTGGCAATGGGAAGC & 55 & 441 & 22 \\
\hline & R GGACACGCCTAAGGAG & & & \\
\hline \multirow[t]{2}{*}{ Beet pseudo-yellows virus } & F TTCATATTAAGGATGCGCAGA & 55 & 334 & 27 \\
\hline & R TGAAAGATGTCCRCTAATGATA & & & \\
\hline \multirow[t]{2}{*}{ Fragaria chiloensis latent virus } & F ACCACTTCACCACCAGATCG & 55 & 300 & 21 \\
\hline & R CAAGCCAACTCACCATGACC & & & \\
\hline \multirow[t]{2}{*}{ Strawberry chlorotic fleck associated virus } & F CGTGGGTGATCGCTAC & 52 & 392 & 23 \\
\hline & R ATACGACGCCTTCTGT & & & \\
\hline \multirow[t]{2}{*}{ Strawberry crinkle virus } & F CATTGGTGGCAGACCCATCA & 58 & 345 & 16 \\
\hline & R TTCAGGACCTATTTGATGACA & & & \\
\hline \multirow{2}{*}{ Strawberry latent ring spot virus } & F CСТCTCCAACCTGCTAGACT & 50 & 497 & 9 \\
\hline & R AAGCGCATGAAGGTGTAACT & & & \\
\hline \multirow{2}{*}{ Strawberry mottle virus } & F GTAGTTTAGTGACAATCCAAGCGGA & 55 & 384 & 15 \\
\hline & R ACATCTCCA/GAACAGTTTATA/TGTCA/GTGT/ATGGAC & & & \\
\hline \multirow[t]{2}{*}{ Strawberry mild yellow edge virus } & F GTGTGCTCAATCCAGCCAG & 52 & 271 & 16 \\
\hline & R CATGGCACTCATTGGAGCTGGG & & & \\
\hline \multirow[t]{2}{*}{ Strawberry necrotic shock virus } & F GAGTATTTCTGTAGTGAATTCTTGGA & 50 & 800 & 20 \\
\hline & R ATTATTCTTAATGTGAGGCAACTRCG & & & \\
\hline \multirow[t]{2}{*}{ Strawberry pallidosis associated virus } & F GTGTCCAGTTATGCTAGGTC & 55 & 517 & 18 \\
\hline & R TAGCTGACTCATCAATAGTG & & & \\
\hline \multirow[t]{2}{*}{ Strawberry veinbanding virus } & F TGAACGCAAAAAATCCTATC & 52 & 472 & 6 \\
\hline & R TGTTCTGAACAGATTGAATC & & & \\
\hline \multirow[t]{2}{*}{$\mathrm{NADH}(\beta)$} & AGTAGATGCTATCACACATACAAT & 55 & 721 & 25 \\
\hline & GGACTCCTGACGTATACGAAGGATC & & & \\
\hline
\end{tabular}

${ }^{a}$ Note: DNA of the $\mathrm{NADH}(\beta)$ has intron and yields an approximately 1,100-bp band.

${ }^{\mathrm{b}}$ Citation with the primer information, polymerase chain reaction conditions, and amplicon size.

Table 2. Viruses detected in major strawberry production areas of the United States and Canada

\begin{tabular}{|c|c|c|c|c|c|c|}
\hline Virus & $\begin{array}{l}\text { Symptomless plants, } \\
\text { California }\end{array}$ & $\begin{array}{l}\text { Declining plants, } \\
\text { California }\end{array}$ & $\begin{array}{c}\text { Pacific } \\
\text { Northwest }\end{array}$ & Midwest & Southeast $^{\mathbf{a}}$ & Northeast $^{\mathrm{a}}$ \\
\hline Apple mosaic virus & $0 / 104$ & $0 / 24$ & $0 / 90$ & $0 / 52$ & $0 / 67$ & $0 / 34$ \\
\hline Beet pseudo-yellows virus & $6 / 104$ & $15 / 24$ & $0 / 90$ & $2 / 52$ & $6 / 67$ & $13 / 72$ \\
\hline Fragaria chiloensis latent virus & $0 / 104$ & $0 / 24$ & $0 / 90$ & $5 / 52$ & $0 / 67$ & $0 / 34$ \\
\hline Strawberry chlorotic fleck associated virus & $0 / 104$ & $0 / 24$ & $0 / 90$ & $0 / 52$ & $0 / 67$ & $0 / 34$ \\
\hline Strawberry crinkle virus & $7 / 104$ & $5 / 24$ & $33 / 90$ & $3 / 52$ & $2 / 122$ & $0 / 72$ \\
\hline Strawberry mottle virus & $8 / 104$ & $6 / 24$ & $62 / 90$ & $6 / 52$ & $64 / 122$ & $36 / 72$ \\
\hline Strawberry mild yellow edge virus & $12 / 104$ & $8 / 24$ & $48 / 90$ & $2 / 52$ & $48 / 122$ & $49 / 72$ \\
\hline Strawberry necrotic shock virus & $5 / 104$ & $0 / 24$ & $3 / 90$ & $1 / 52$ & $1 / 122$ & $1 / 72$ \\
\hline Strawberry pallidosis associated virus & $11 / 104$ & $18 / 24$ & $1 / 90$ & $19 / 52$ & $13 / 67$ & $7 / 72$ \\
\hline Strawberry veinbanding virus & $11 / 104$ & $4 / 24$ & $43 / 90$ & $3 / 52$ & $2 / 122$ & $1 / 72$ \\
\hline
\end{tabular}

a Viruses with a greater number of assays completed were due to sampling in autumn 2012 in response to plant decline in nurseries in Nova Scotia and fruiting fields in the southeast; see text for further explanation. 
conditions changed, such that the latent period is fulfilled in less time? We probably will not be able to solve this conundrum because only a single isolate of SCV predating 1990 is available, and colonies of Chaetosiphon fragaefolii from the time when SCV was extremely rare in the Fraser Valley are lacking.

The very recent detection of Strawberry mild yellow edge virus (SMYEV) and Strawberry mottle virus (SMoV) in declining strawberry in the Great Village area of Nova Scotia highlights the importance of implementing some virus testing at the last stage in production of certified plants. Many of the strawberry plants for fruit production in the southeastern United States originate in nurseries in Canada. Currently, testing is carried out at the higher levels of the certification program in a manner very similar to what is done in U.S. nurseries, with visual inspection at the last stage of increase in the program. Millions of plants shipped from nurseries in this area of Nova Scotia for fruit production in the southeastern United States failed to develop properly over the winter and produce fruit in the Florida production system. Stunted plants tested from Florida, South Carolina, North Carolina, Virginia, and Maryland that had originated from the affected nurseries tested positive for SMYEV and SMoV. This is an example of inadvertent movement of plant viruses that is having a large impact on production at a distant location. Plants from nurseries in other areas of Nova Scotia and Prince Edward Island did not exhibit decline symptoms and did not test positive for SMYEV and SMoV.

The information provided here can be used to identify high risk viruses of strawberry by region. This can be used by growers to manage virus diseases in production fields, by nurseries to emphasize control of viruses most likely to spread in the area where the nursery is located, and by state departments of agriculture that carry out certification programs to target their efforts on high-risk or "canary" viruses, which are most likely to spread into nursery stocks in their state or province. It is clear that individual viruses do not cause observable disease in strawberry, highlighting the importance of indexing nursery stocks and not relying on visual inspections to determine virus status of plants. Nurseries should aim to control all viruses to minimize the risk of distributing viruses to production fields in the same region and to minimize the risk of trafficking viruses between states and countries with plant materials. If nurseries start out with plants free of known viruses, then monitoring should focus on viruses that are known to spread in the area, with some testing for other viruses at the top two tiers of propagation. For fruit growers that use an annual plasticulture cropping system or those using the matted-row system with perennial plantings, where the major vectors strawberry aphid (4) and the greenhouse whitefly (10) are lacking or at very low populations, it should not be necessary to control viruses in production

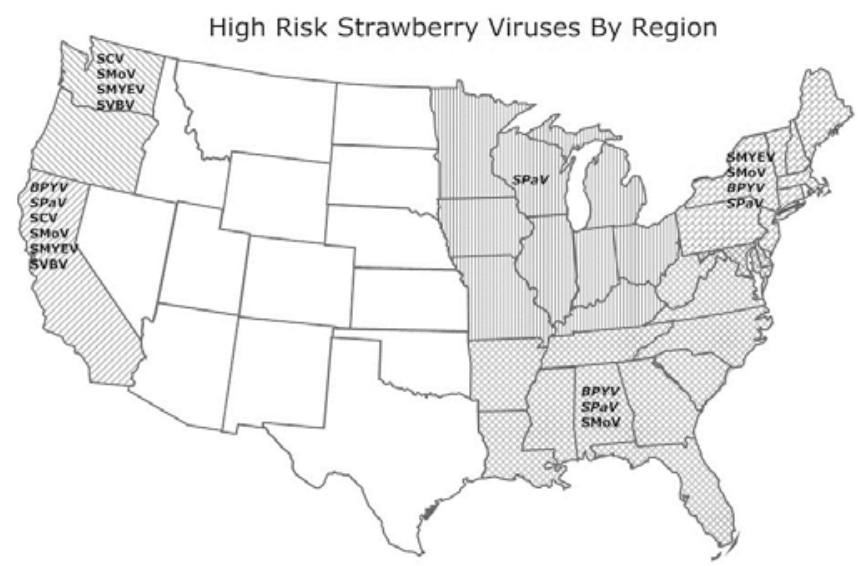

Fig. 2. High-risk strawberry viruses by region in the United States and Canada. Strawberry mottle virus (SMoV), Strawberry mild yellow edge virus (SMYEV), Strawberry crinkle virus (SCV), Strawberry veinbanding virus (SVBV), Strawberry pallidosis associated virus (SPaV), and Beet pseudo yellows virus (BPYV). Acronyms in italics represent whitefly-transmitted viruses and acronyms in normal text represent aphid-transmitted viruses. fields. Fruit growers using the perennial matted-row system in areas with high populations of the strawberry aphid do need to implement control measures to slow the spread and impact of virus diseases. Because the four major aphid-transmitted viruses each have different virus-vector interactions $(4,7)$, it is important to know which viruses are present in the area because aphid management will be very different for nonpersistent transmission compared with persistent or propagative persistent transmission.

The recent examples of strawberry virus infection in nurseries in California in 2002 and 2003 and Nova Scotia in 2012 highlight the importance of implementing some level of laboratory testing at the final increase stage for strawberry nurseries. Testing for the highest-risk or canary virus for the region would be a relatively easy and inexpensive and safeguard against a serious virus outbreak. In each of these cases, sampling that had a 95\% confidence level of detecting a $5 \%$ infection rate would have detected the problem prior to digging plants in the nursery. This level of testing only requires 59 samples per field (1); thus, an enzyme-linked immunosorbent assay-based assay in which composite sampling of four leaves was able to detect the virus would be easy to implement. Because single infections rarely cause visual symptoms in commercial strawberry cultivars, visual inspections can easily miss virus infections that can lead to disasters in fruiting fields. Certification guidelines need to be updated to take advantage of wellproven and effective testing technologies to strengthen these programs. The newly formed National Clean Plant Network is in a position to promote these improvements to certification programs and promote similar improvements at the international level. These cases also highlight the importance of harmonizing certification standards across areas where plants are distributed from nurseries to areas for fruit production. In strawberry as well as for many other crops, these plants are often shipped across state and, in some cases, international boundaries; thus, certification harmonization at as broad a scale as possible would be most effective.

\section{Acknowledgments}

Financial support was provided by the California Strawberry Commission, Oregon Strawberry Commission, Washington Strawberry Commission, Fraser Valley Strawberry Growers Association, North American Strawberry Growers Association, The Northwest Center for Small Fruit Research, the National Clean Plant Network, the USDA-ARS and the Arkansas Agricultural Experimental Station. We thank P. Byers, A. Dale, C. Finn, M. Ellis, R. Gergerich, A. Jamieson, J. Lewis, F. Louws, P. McManus, D. Marcum, J. Mertley, M. Nelson, N. Peres, B. Poling, A. Schilder, G. Schnabel, T. Walters, C. Weber, W. Wintermanel, B. Hughes, T. Bauman, M. Bolda, B. Hughes, M. Kong, A. Laney, T. Nourse, R. Tritten, and M. Sweeney, for providing strawberry samples.

\section{Literature Cited}

1. Anonymous. 2008. International Standards for Phytosanitary Measures, ISPM No. 31, Methodologies for Sampling of Consignments. Produced by the Secretariat of the International Plant Protection Convention.

2. Anonymous. 2012. http://faostat.fao.org/site/567/DesktopDefault.aspx?Page ID $=567 \#$ \#ancor

3. Anonymous. 2012. U.S. Strawberry Industry. http://usda.mannlib.cornell. edu/MannUsda/viewDocumentInfo.do?documentID=1381

4. Converse, R. H. 1987. Virus and viruslike diseases of Fragaria (strawberry). Pages 1-100 in: Virus Diseases of Small Fruits. R. H. Converse, ed. U. S. Dep. Agric. Agric. Res. Serv. Agric. Handb. No 631. Washington, DC.

5. Krczal, H. 1982. Investigations of the biology of the strawberry aphid (Chaetosiphon fragaefolli), the most important vector of strawberry viruses in West Germany. Acta Hortic. 129:63-68.

6. Mahmoudpour, M. M. A. 2000. Strawberry vein banding caulimovirus: biology and characterization. Ph.D. diss. University of California, Davis.

7. Martin, R. R., and Spiegel, S. 1998. Virus section. Pages 62-75 in: Compendium of Strawberry Diseases, 2nd ed. American Phytopathological Society, St. Paul, MN

8. Martin, R. R., and Tzanetakis, I. E. 2006. Characterization and recent advances in detection of strawberry viruses. Plant Dis. 90:384-396.

9. Martin, R. R., Tzanetakis, I. E., Barnes, J. E., and Elmhirst, J. F. 2004. First report of Strawberry latent ringspot virus in strawberry in the United States and Canada. Plant Dis.88:575.

10. Mass, J., ed. 1998. Compendium of Strawberry Diseases, 2nd ed. American Phytopathological Society, St. Paul, MN.

11. McKee, G. J., Goodhue, R. E., Chalfant, J. A., Carter, C. A., and Zalom, F. G. 2009. Population dynamics and the economics of invasive species management: The greenhouse whitefly in California-grown strawberries. J. 
Environ. Manage. 90:561-570.

12. Moore, P. P., Sjulin, T. M., and Shanks, C. H., Jr. 1995. 'Puget Reliance' strawberry. HortScience 30:1468-1469.

13. Spiegel, S., and Martin R. R. 1993. Improved detection of potato leafroll virus in dormant potato tubers and microtubers by the polymerase chain reaction and ELISA. Ann. Appl. Biol. 122:493-500.

14. Spiegel, S., Martin, R. R., Legget, F., ter Borg, M., and Postman, J. 1993. Characterization and geographical distribution of a new ilarvirus from Fragaria chiloensis. Phytopathology 83:991-995.

15. Thompson, J. R., Leone, G., Lindner, J. L. Jelkmann, W., and Schoen, C. D. 2002. Characterization and complete nucleotide sequence of Strawberry mottle virus: a tentative member of a new family of bipartite plant picornalike viruses. J. Gen. Virol. 83:229-239.

16. Thompson, J. R., Wetzel, S., Klerks, M. M. Vašková, D., Schoen, C. D., Spak, J., and Jelkmann, W. 2003. Multiplex RT-PCR detection of four aphid-borne strawberry viruses in Fragaria spp. in combination with a plant mRNA specific internal control. J. Virol. Methods 111:85-93.

17. Tzanetakis, I. E. 2004. Molecular characterization of criniviruses and ilarviruses infecting strawberry. Ph.D. diss. Oregon State University, Corvallis.

18. Tzanetakis, I. E., Halgren, A. B., Keller, K. E., Hokanson, S. C., Maas, J. L., McCarthy, P. L., and Martin, R. R. 2004. Identification and detection of a virus associated with strawberry pallidosis disease. Plant Dis.88:383-390.

19. Tzanetakis, I. E., Halgren, A. B., Mosier, N., and Martin, R. R. 2007. Identification and characterization of Raspberry mottle virus, a novel member of the Closteroviridae. Virus Res. 127:26-33
20. Tzanetakis, I. E., Mackey, I. C., and Martin R. R. 2004. Strawberry necrotic shock virus is a distinct virus and not a strain of Tobacco streak virus. Arch. Virol. 149:2001-2011.

21. Tzanetakis, I. E., and Martin, R. R. 2005. New features of the genus Ilarvirus revealed by the nucleotide sequence of Fragaria chiloensis latent virus. Virus Res. 112:32-37.

22. Tzanetakis, I. E., and Martin, R. R. 2005. First report of strawberry as a natural host of Apple mosaic virus. Plant Dis. 89:431.

23. Tzanetakis, I. E., and Martin, R. R. 2007. Strawberry chlorotic fleck: Identification and characterization of a novel Closterovirus associated with the disease. Virus Res. 124:88-94

24. Tzanetakis, I. E., Martin, R. R., and Scott, S. W. 2010. Genomic sequences of Blackberry chlorotic ringspot virus and Strawberry necrotic shock virus and the phylogeny of viruses in subgroup 1 of the genus Ilarvirus. Arch. Virol. 155:557-561.

25. Tzanetakis, I. E., Postman, J. D., and Martin, R. R. 2007. Identification, detection and transmission of a new Vitivirus from Mentha. Arch. Virol 152:2027-2033.

26. Tzanetakis, I. E., Wintermantel, W. M., Cortez, A. A., Barnes, J. E., Barrett, S. M., Bolda, M. P., and Martin, R. R. 2006. Epidemiology of Strawberry pallidosis associated virus and occurrence of pallidosis disease in North America. Plant Dis. 90:1343-1346

27. Tzanetakis, I. E., Wintermantel, W. M., and Martin, R. R. 2003. First report of Beet pseudo yellows virus in strawberry in the United States: A second crinivirus able to cause pallidosis disease. Plant Dis. 87:1398. 